\title{
ANTI-Lentivirus, Brucella abortus AND B. ovis ANTIBODIES IN SMALL RUMINANTS RAISED IN PERNAMBUCO AND BAHIA ${ }^{1}$
}

\author{
RODOLFO DE MORAES PEIXOTO ${ }^{2 *}$; GRACE BARBOSA DOS SANTOS ${ }^{3}$; EVANDRO SANTOS AMANSO EN $^{3}$ \\ MARIA DA CONCEIÇÃO AQUINO DE SÁ3 ${ }^{3}$; RENATA DE MORAES PEIXOTO ARAÚJO' ${ }^{3}$; MATEUS MATIUZZI DA \\ $\operatorname{COSTA}^{3}$
}

\begin{abstract}
Goat and sheep production in the semi-arid northeast of Brazil has shown great economic potential. However, health problems can compromise the productivity of these animals. Given the scarcity of studies about the occurrence of these diseases, the aim of the present study was to analyze the serological diagnosis of anti-Brucella and anti-lentivirus antibodies among small ruminants in municipalities located in the Brazilian states of Bahia and Pernambuco. The samples were collected from local slaughterhouses and dairy farms. In total, 997 serum samples from animals in slaughterhouses and dairy herds were collected. In order to diagnose the caprine arthritis encephalitis virus (CAEV), the samples underwent agarose gel immunodiffusion (AGID) testing. The buffered acidified antigen test (goats) and agarose gel immunodiffusion test (sheep) were used to detect anti-Brucella abortus and B. ovis antibodies following the methodology recommended by the Institute of Technology of Paraná (TECPAR). With anti-CAEV antibodies, seropositivity rates of $4.1 \%$ and $2.2 \%$ were recorded for animals from the slaughterhouses and dairy farms, respectively. None of the animals (goats or sheep) were positive for anti-B. abortus antibodies. With B. ovis, a seropositivity rate of $6.5 \%(\mathrm{n}=13)$ was recorded among the 199 sheep serum samples. Results of the present study confirmed the presence of the CAE virus in the meat and dairy herds studied, although the prevalence was low. Natural infection by $B$. abortus did not occur in the goat and sheep herds assessed. Seropositivity for B. ovis was confirmed, although prevalence was low. Direct tests are required to diagnose ovine brucellosis.
\end{abstract}

Keywords: Brucellosis. CAEV. Goats. Sheep. Serology.

\section{ANTICORPOS ANTI-Lentivírus, Brucella abortus E B. ovis EM PEQUENOS RUMINANTES CRIADOS EM PERNAMBUCO E BAHIA}

\begin{abstract}
RESUMO - Alguns problemas de ordem sanitária ainda comprometem a produtividade de caprinos e ovinos. Sendo assim, foi realizado um estudo de diagnóstico sorológico da presença de anticorpos anti-lentivírus e antiBrucella em pequenos ruminantes localizados em municípios dos estados da Bahia e Pernambuco. As coletas foram realizadas em estabelecimentos de abate e em propriedades rurais com produção de leite, totalizando 997 amostras de soro. Para o diagnóstico do CAEV, as amostras foram submetidas ao teste de Imunodifusão em Gel de Agarose (IDGA). Para a pesquisa de anticorpos anti-Brucella abortus e Brucella ovis, foram utilizadas as técnicas do Antígeno Acidificado Tamponado (caprinos) e Imunodifusão em Gel de Agarose (ovinos), utilizando-se antígeno e metodologia recomendada pelo Instituto de Tecnologia do Paraná-TECPAR. Na pesquisa de anticorpos anti-CAEV, observou-se uma soropositividade de 4,1 e 2,2\% para os animais oriundos de estabelecimentos de abate e de propriedades leiteiras, respectivamente. Quanto à pesquisa de anticorpos antiB.abortus em caprinos e ovinos, não se observou nenhum animal positivo. Em relação a B. ovis, pesquisada em 199 amostras de soro ovino, obteve-se uma soroposividade de 6,5\% $(\mathrm{n}=13)$. Pode-se demonstrar a presença do vírus do CAEV nos rebanhos de corte e leite estudados, porém em baixa frequência. Por outro lado, a infecção natural pela Brucella abortus não ocorre nos rebanhos de caprinos e ovinos avaliados. Registra-se a soropositividade para Brucella ovis, porém em baixa frequência, sendo necessária a realização de testes diretos para diagnóstico da brucelose ovina.
\end{abstract}

Palavras-chave: Brucelose. CAEV. Caprinos. Ovinos. Sorologia.

\footnotetext{
*Corresponding author

${ }^{1}$ Received for publication in $01 / 21 / 2015$; accepted in $02 / 16 / 2016$.

Paper extracted from the Master of Science dissertation of the first author.

${ }^{2}$ Area of Animal Sciences, Instituto Federal de Educação, Ciência e Tecnologia do Sertão Pernambucano, Petrolina, PE, Brazil; rmpeixoto.vet@gmail.com.

${ }^{3}$ Area of Animal Sciences, Universidade Federal do Vale do São Francisco, Petrolina, PE, Brazil; gracebarbosa.santos@gmail.com, evandroamanso@hotmail.com, ceicazoo@hotmail.com,rata_bios@yahoo.com.br, mateus.costa@univasf.edu.br.
} 


\section{INTRODUCTION}

The Brazilian economy has benefitted from the steep growth of goat and sheep production in several Brazilian states. In 2012, the Instituto Brasileiro de Geografia e Estatística (IBGE) recorded a national herd of 25.42 million head (16.78 million sheep and 8.64 million goats). The highest levels of production are found in the Northeast of the country, with $91 \%$ of all production in 2012 recorded in this region. The states of Pernambuco and Bahia contain approximately nine million small ruminants (IBGE, 2012). However, the production and productivity of these animals can be affected by several factors, particularly nutrition, general management conditions, and sanitary conditions. Of the sanitary issues, the most significant are infectious and parasitic diseases, which can lead to severe economic losses owing to the poor quality of meat and/or milk, as well as high mortality rates (ALENCAR et al., 2010). Viruses and bacteria cause diseases that threaten the development of the goat and sheep industries in Brazil.

The caprine arthritis encephalitis virus (CAEV), a lentivirus of the Retroviridae family, affects small ruminants and causes chronic disease (LARRUSKAIN; JUGO, 2013). This virus can lead to sub-clinical inflammation in one or more organs, mainly affecting the joints, nervous system, mammary glands, and respiratory system (BLACKLAWS et al., 2004). Caprine arthritis encephalitis (CAE) has been recorded worldwide (PETERHANS et al., 2004), is mainly found in dairy herds, and has been correlated with economic losses (ANDRIOLI et al., 2006). It is primarily transmitted to newborns via the colostrum; transmission can also occur via aerosol, animal-to-animal contact, and mating (PETERHANS et al., 2004; LE JAN et al., 2005).

Brucellosis is another disease with great economic significance. This infectious-contagious disease exhibits zoonotic potential and mainly affects cattle, goats and sheep (PINHEIRO JUNIOR et al., 2008). It has been recorded all over the world and its etiology involves facultative intra-cellular bacteria of the genus Brucella (species-specific), of which six are the most widely recognized (CASTRO et al., 2005; SALABERRY et al., 2011).

An infected animal is the main source of infection for humans and other animals, and is typically a result of direct contact with secretions, fomites and contaminated food (CARNEIRO et al., 2005). Goats and sheep (although less common in the latter) may manifest systemic signs including fever, apathy, weight loss, diarrhea, mastitis, lameness, and orchitis (in males) (SMITH, 1986).

Given the scarcity of studies on the occurrence of these diseases, particularly brucellosis, the aim of the present study was to conduct a serological diagnosis of the circumstances of these diseases among small ruminants in municipalities located in the Brazilian states of Pernambuco and Bahia.

\section{MATERIAL AND METHODS}

The present study received approval from the Human and Animal Research Ethics Committee of the Universidade Federal do Vale do São Francisco under protocol number 27091054.

The study region comprised the bipole of Petrolina (Pernambuco) and Juazeiro (Bahia), as well as the municipality of Valente (Bahia), the main characteristics of which are the semi-arid climate and the native caatinga vegetation.

The collections were made at slaughterhouses and on rural milk production properties. Blood samples were collected from 120 goats and 385 sheep at the municipal slaughterhouse in Petrolina (PE) and from 134 sheep in the LAMM slaughterhouse in Juazeiro (BA), for a total of 639 animals from slaughterhouses. Sampling of milkproducing animals was performed at 15 goat-milk production properties in the municipality of ValenteBA, totaling 358 dairy animals. By adding the samples taken from the slaughterhouses $(n=639)$ to the samples taken from the dairy herds $(\mathrm{n}=358)$, a total of 997 blood samples were collected. Nonprobabilistic convenience sampling was used, as described by Thrusfield (2004).

The analysis was conducted in the Microbiology and Animal Immunology Laboratory of the UNIVASF, on the Agrarian Sciences campus in the city of Petrolina (PE). In order to perform the collections, the animals were restrained and submitted to antisepsis of the jugular vein with iodized alcohol. The blood samples (a volume of approximately $10 \mathrm{~mL}$ ) were collected through jugular venipuncture using disposable hypodermic needles $(40 \times 12 \mathrm{~mm})$. In order to obtain the serum, this volume remained in the tube until the compete retraction of the blood clot. The material was centrifuged $(2500 \mathrm{rpm} / 5 \mathrm{~min})$ and then stored in microtubes $(1.5 \mathrm{~mL})$ at $-20^{\circ} \mathrm{C}$ until the serological examinations were conducted.

In order to diagnose CAEV, the serum samples were submitted to the agarose gel immunodiffusion (AGID) test, using a Biovetech kit (Indústria e Comércio de Produtos Biotecnológicos Ltda ME), which involves the use of the CAEV p28 capsid protein as the antigen. After the distribution of the test, control, and antigen in the agarose gel, these serum were incubated at room temperature in a humid chamber for $72 \mathrm{~h}$. The serum were considered positive when a line of precipitation formed between the central well (antigen) and the serum being tested, exhibiting its identity with the formation of a line between the positive control serum and the antigen (ARRUDA et al., 2011). 
The buffered acidified antigen technique (goats) and the agarose gel immunodiffusion test (sheep) were used to assess anti-Brucella abortus and $B$. ovis antibodies, based on the antigen and methodology recommended by the Instituto de Tecnologia do Paraná (TECPAR). Normative Instruction SDA No. 06 from January 8, 2004 was used to diagnose caprine brucellosis (BRASIL, 2004). For the buffered acidified antigen test, $30 \mu \mathrm{L}$ of serum was deposited on a glass plate beside an equal volume of the antigen. The serum and antigen were then mixed for 2 min using circular movements, and the results were analyzed in an indirect light box. The serum that exhibited agglutination were designated as collected from reagent animals, whereas those without agglutination were from non-reagent animals (BRASIL, 2003).

Descriptive statistics, the distribution of the relative and absolute frequencies of the results obtained in the serological tests, were used. Inferential statistics were used to determine the correlation between seropositivity for CAEV and the variable zootechnical function (meat/milk), based on the chi-squared test with a significance level of $p<$ 0.05 (THRUSFIELD, 2004).

\section{RESULTS AND DISCUSSION}

In the survey of anti-CAEV antibodies, a seropositivity rate of $4.1 \%$ was recorded for animals from slaughterhouses (Table 1). No statistically significant association was found between seropositivity and the variable zootechnical function $(p=0.260)$. The current literature contains very few serological surveys that sought to diagnose CAEV among animals destined for slaughter, because this disease is more commonly correlated with dairy herds and intensive management systems used in milk production. Similar results were obtained by Oliveira et al. (2006), who reported a prevalence rate of $3.8 \%$ for CAEV among goat serum samples. The concordance between these studies may be due to their similarities, because they were both conducted in slaughterhouses in the same state. In the Northeast region of Brazil, it is common for farmers to keep dairy animals and those specialized in meat production together, thereby favoring the transmission of the disease. In addition, on many sites, animals are raised with a dual zootechnical purpose, which favors the dissemination of the agent.

A seropositivity rate of $2.2 \%$ was recorded in the dairy herds studied. A study by Castro et al. (1994) reported that the prevalence ranged from $0 \%$ to $29.5 \%$ on dairy properties in the state of Pernambuco. Almeida et al. (2001) conducted a serological study to determine the prevalence of CAEV in the state of Bahia and found that 215 of 1605 blood serum samples (13.4\%) examined were positive in the AGID test, with the highest prevalence rates found among breeds that specialized in milk production.

Table 1. Use of agarose gel immunodiffusion (AGID) to analyze anti-lentivirus antibodies of CAEV in dairy and meat goats raised in the states of Pernambuco and Bahia.

\begin{tabular}{|c|c|c|c|}
\hline \multirow{2}{*}{ Herd/Type } & \multirow{2}{*}{ No. of animals } & \multicolumn{2}{|c|}{ AGID } \\
\hline & & Negative & Positive \\
\hline Dairy $^{1}$ & 358 & $350(97.8 \%)$ & $08(2.2 \%)$ \\
\hline Total & 478 & $465(97.3 \%)$ & $13(2.7 \%)$ \\
\hline
\end{tabular}

${ }^{1}\left(\chi^{2}=1.27 ; p>0.05\right)$.

The low prevalence of positive animals in the present study may have been caused by the acquisition of these animals in suitable locations. In addition, fairs and expositions in the region examined in this study currently demand proof of negativity for $\mathrm{CAEV}$, which helps to maintain the sanitary status of herds.

Studies have shown that the disease probably arrived in Brazil through the import of animals infected with the virus from Europe or the Unites States of America (PINHEIRO et al., 2007). Considering the heterogeneous nature of the goat population in Brazil, many breeds came from European countries where the prevalence of this disease is relatively high (BERTOLINI et al., 1997).

Although the AGID test is the main method of detecting CAEV and has been recommended by the World Organization for Animal Health (OIE), it is limited in terms of identifying animals that are in the initial stages of the infection. Not all infected animals will be shown to be seropositive in this test, since delayed seroconversion is a possibility (CONTRERAS et al., 2001; FROTA et al., 2005). Thus, molecular techniques of viral detection have been used to provide an early diagnosis of the disease. One of these techniques is polymerase chain reaction (PCR), the aim of which is in vitro amplification of nucleic acids, thereby enabling the attainment of thousands of copies of a specific DNA sequence without the need for a bodily response such as the production of antibodies (ANDRIOLI et al., 2006).

Regarding the survey of anti-B. abortus antibodies in goats and sheep, the seronegativity recorded was $100 \%$ (Table 2). Peixoto et al. (2008) also reported $100 \%(\mathrm{n}=222)$ seronegativity while searching for anti-B. abortus antibodies in goats raised in the sub-medium São Francisco region. 
However, a recent study by Pinheiro Junior et al. (2008) reported the first occurrence of seropositivity for $B$. abortus among sheep and goats in the Sertão region of Pernambuco. The same authors reported prevalence rates of $0.6 \%$ and $2.5 \%$ among the goats and sheep that were positive for $B$. abortus, respectively. The concordance of the findings could reflect similarities observed in the studies with respect to the management conditions, the number of animals assessed and the region studied.

Table 2. Result of the buffered acidified antigen (BAA) and agarose gel immunodiffusion (AGID) tests for Brucella abortus and B. ovis among goats and sheep raised in the states of Pernambuco and Bahia.

\begin{tabular}{ccccc}
\hline \multirow{2}{*}{ Species } & \multicolumn{2}{c}{ BAA - B. abortus } & \multicolumn{2}{c}{ AGID - B. ovis } \\
\cline { 2 - 5 } & Non-reagents & Reagents & Negative & Positive \\
\hline Goat & 120 & 0 & NA* & NA \\
Sheep & 400 & 0 & 186 & 13 \\
\hline
\end{tabular}

*NA $=$ not assessed.

In the survey of B. ovis performed using 199 blood serum samples, the seropositivity recorded was $6.5 \%(\mathrm{n}=13)$. In a study conducted in the Agreste region of Pernambuco, Pinheiro Junior et al. (2005) reported a prevalence of $4.76 \%$ for sheep that were positive for $B$. ovis. Clementino et al. (2007) conducted an epidemiological survey of the risk $\mathrm{f}$ actors associated with infection by $B$. ovis among wool-less rams in the state of Paraíba and reported a prevalence rate of $8.59 \%(\mathrm{n}=25)$ for all properties visited (283). The low seroprevalence found could have been due to the small number of animals in each of the herds assessed and the extensive breeding system, which decreased the probability of infection.

\section{CONCLUSION}

The presence of the CAE virus could be confirmed in the herds studied, although the prevalence was low. This result is significant, given that studies of this type of herd (meat) are rare. Preventive sanitary measures must be implemented in these types of production systems. Conversely, natural infection with $B$. abortus did not occur in the goat and sheep herds studied. Seropositivity was recorded for $B$. ovis, although it was detected at low levels. Direct tests are needed to diagnose ovine brucellosis.

\section{REFERENCES}

ALENCAR, S. P. et al. Perfil sanitário dos rebanhos caprinos e ovinos no sertão de Pernambuco. Ciência Animal Brasileira, Goiânia, v. 11, n. 1, p. 131-140, 2010 .

ALMEIDA, M. G. A. R. et al. Dados sorológicos sobre a presença e distribuição da artrite-encefalite caprina (CAE) no Estado da Bahia, Brasil. Revista Brasileira de Saúde e Produção Animal, Salvador, v. 1, n. 3 , p. $78-83,2001$.

ANDRIOLI, A. et al. Fatores de risco na transmissão do lentivírus caprino pelo sêmen. Pesquisa Agropecuária Brasileira, Brasília, v. 41, n. 8, p. 1313-1319, 2006.

ANDRIOLI, A.; et al. Protocolos para extração do DNA-proviral e PCR do lentivírus caprino em sangue. Sobral: Embrapa Caprinos, 2006. 5p. (Comunicado Técnico, 72). Disponível em: <http:// www.infoteca.cnptia.embrapa.br/handle/ doc/533316>. Acesso em 30 out.2014.

ARRUDA, E. T. et al. Avaliação de uma microimunodifusão em gel de ágar para diagnóstico de lentivírus de pequenos ruminantes (LVPR) em caprinos. Ciência Animal Brasileira, Goiânia, v. 12 , n. 3, p. 560-565, 2011.

BERTOLINI, D. A.; SANTOS, G. T.; MIRANDANETO, M. H. Compilação de dados sobre a epidemiologia e profilaxia da artrite encefalite caprina. Arquivos de Ciências da Saúde da UNIPAR, Umuarama, v. 1, n. 1, p. 17-26, 1997.

BLACKLAWS, B. A. et al. Transmission of small ruminant lentiviruses. Veterinary Microbiology, Amsterdã, v. 101, n. 3, p. 199-208, 2004.

BRASIL. Programa Nacional de Controle e Erradicação da Brucelose e Tuberculose Bovina, Ministério da Agricultura e do Abastecimento, Departamento de Defesa Animal, p. 9, 2003.

BRASIL. Programa Nacional de Controle e Erradicação da Brucelose e Tuberculose Bovina, Instrução Normativa SDA No 06, 2004.

CARNEIRO, J. et al. Investigação da soropositividade para brucelose em rebanhos caprinos produtores de leite para consumo humano. Revista Brasileira de Saúde e Produção Animal, Salvador, v. 6, n. 2, p. 53-58, 2005.

CASTRO, R. S.; NASCIMENTO, S. A.; ABREU, S. R. O. Evidência sorológica de infecção pelo vírus da artrite-encefalite caprina em caprinos leiteiros do Estado de Pernambuco. Arquivo Brasileiro de 
Medicina Veterinária e Zootecnia, Belo Horizonte, v. 46, n. 5, p. 571-572, 1994.

CASTRO, H. A.; GONZÁlEZ, S. F.; PRAT, M. I. Brucelosis: una revisión práctica. Acta Bioquímica Clínica Latinoamericana, Buenos Aires, v. 39, n. 2, p. 203-16, 2005.

CLEMENTINO, I. J. et al. Inquérito soroepidemiológico e fatores de risco associados à infecção por Brucella ovis em carneiros deslanados do semiárido da Paraíba. Pesquisa Veterinária Brasileira, Seropédica, v. 27, n. 4, p. 137-143, 2007.

CONTRERAS, A. et al. Etiología de la infección intramamaria caprina en relación con los programas de control. In: JORNADA CIENTIFICA DE LA SEOC, 26, 2001, Sevilla. Anais... Sevilla: SEOC, 2001, p. 71-83.

FROTA, M. N. L. et al. Artrite Encefalite Caprina em cabritos de rebanhos com programa de controle no Estado do Ceará. Arquivos do Instituto Biológico, São Paulo, v. 72, n. 2, p. 147-152, 2005.

IBGE. Instituto Brasileiro de Geografia e Estatística. Efetivo animal nos estados do Nordeste do Brasil. Disponível em: <http://www.ibge.gov.br/estadosat/ index.php>. Acesso em: 14 out. 2014.

LARRUSKAIN, A.; JUGO, B. M. Retroviral Infections in Sheep and Goats: Small Ruminant Lentiviruses and Host Interaction. Viruses, Basel, v. 5, n. 8, p. 2043-2061, 2013.

LE JAN, C. et al. Mammary transmission of caprine arthritis encephalitis virus: a 3D model for in vitro study. Reproduction Nutrition Development, Les Ulis, v. 45, n. 4, p. 513-523, 2005.

OLIVEIRA, M. M. M. et al. Anticorpos contra lentivírus de pequenos ruminantes em caprinos e ovinos em abatedouros do estado de Pernambuco. Arquivo Brasileiro de Medicina Veterinária e Zootecnia, Belo Horizonte, v. 58, n. 5, p. 947-949, 2006.

PEIXOTO, R. M. et al. Inquérito soroepidemiológico anti-Brucella abortus em rebanhos caprinos na região Semiárida do Submédio São Francisco, PE. In: CONGRESSO NORDESTINO DE PRODUÇÃO ANIMAL, 5, 2008, Aracaju. Anais... Aracaju: SNPA, 2008. p. 1-3.

PETERHANS, E. et al. Routes of transmission and consequences of small ruminant lentiviruses (SRLVs) infection and eradication schemes. Veterinary Research, Jouy-en-Josas, v. 35, n. 3, p. 257-274, 2004.
PINHEIRO, R. R.; ALVES, S. F. S.; ANDRIOLI, A. Enfermidades Infeciosas de Pequenos Ruminantes: Epidemiologia, Impactos Econômicos, Prevenção e Controle: Uma Revisão. Revista Brasileira de Higiene e Sanidade Animal, Fortaleza, v. 1. n. 1, p. 44-66, 2007.

PINHEIRO JUNIOR, J. W. et al. Levantamento soro -epidemiológico anti-Brucella abortus e B. ovis em rebanhos caprinos e ovinos no estado de Pernambuco. In: CONGRESSO DE INICIAÇÃO CIENTÍFICA, 15, 2005, Recife. Anais... Recife: UFRPE, 2005.

PINHEIRO JUNIOR, J. W. et al. Frequência de aglutininas anti-Brucella abortus em caprinos e ovinos do sertão do estado de Pernambuco, Brasil. Ciência Animal Brasileira, Goiânia, v. 9, n. 4, p. 1096-1101, 2008.

SALABERRY, S. R. S. Pesquisa de anticorpos antiBrucella abortus e anti-Brucella ovis em ovinos no município de Uberlândia, MG. Arquivo Brasileiro Medicina Veterinária e Zootecnia, Belo Horizonte, v. 63 , n. 4, p. 1022-1024, 2011.

SMITH, M. C. Causes and diagnosis of abortion in goats. In: MORROW, D. A. Current therapy in theriogenology, 2. ed. Philadelphia, USA: WB Saunders, 1986, $600 \mathrm{p}$.

THRUSFIELD, M. V. Epidemiologia Veterinária. $2^{\mathrm{a}}$ ed. São Paulo: ROCA, 2004, 556 p. 